\title{
A cRNA Probe Detects Prunus Necrotic Ringspot Virus in Three Peach Cultivars after Micrografting and in Peach Shoots following Long-term Culture at $4{ }^{\circ} \mathrm{C}$
}

\author{
K. Heuss ${ }^{1}$, Q. Liu' ${ }^{2}$, and F.A. Hammerschlag ${ }^{3}$ \\ U.S. Department of Agriculture, Agricultural Research Service, Fruit \\ Laboratory, Beltsville, MD 20705-2350

\section{R.W. Hammond ${ }^{4}$ \\ U.S. Department of Agriculture, Agricultural Research Service, Molecular Plant Pathology Laboratory, Beltsville, MD 20705-2350}

Additional index words. autografts, heterografts, Prunus persica, tissue culture, virus detection

\begin{abstract}
As part of a program to develop transgenic peach (Prunus persica L. Batsch) cultivars with resistance to Prunus necrotic ringspot virus (PNRSV), we are testing a system for measuring virus in peach shoot cultures. Micrografting in vitro is used for inoculation and slot-blot hybridization, with a digoxigenin (DIG)-labeled cRNA probe complementary to the 5' open reading frame (ORF) of PNRSV RNA 3, for detection. In this study, we investigated whether infected shoots maintain virus infection over long periods of culture at $4{ }^{\circ} \mathrm{C}$ and if PNRSV-infected 'Suncrest' shoot cultures can serve as graft bases to transmit virus equally well into cultivars Nemaguard, Springcrest, and Suncrest. The results of RNA hybridization analysis showed that virus was present in extracts of leaf samples from 2-year-old PNRSV-infected 'Suncrest' shoots that had been subjected to varying lengths of incubation at $4{ }^{\circ} \mathrm{C}$ in the dark, suggesting that infected shoots can be maintained for repeated use. Rates of graft success were higher in heterografts between 'Suncrest' bases and tips of 'Springcrest' or 'Nemaguard' than in autografts between 'Suncrest' and 'Suncrest', and there was equal efficacy of graft inoculation from 'Suncrest' into these three cultivars.
\end{abstract}

Our long-term objective is to develop peach trees resistant to Prunus necrotic ringspot virus (PNRSV) via genetic engineering. Similar approaches have been effective in producing resistance to many types of plant viruses, including several members of the ilarvirus group (Hull and Davies, 1992), which includes PNRSV. This approach depends on developing a reliable method for evaluating transgenic plants for resistance to PNRSV.

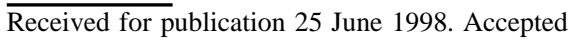
for publication 10 Aug. 1998. We extend special thanks to Mary Camp for assistance with statistical analyses. Use of company or product name does not imply approval or recommendation of the product to the exclusion of others, which may also be suitable. The cost of publishing this paper was defrayed in part by the payment of page charges. Under postal regulations, this paper therefore must be hereby marked advertisement solely to indicate this fact. ${ }^{1}$ Research Geneticist. Current address: Agronomy Dept., Univ. of Nebraska, 350 Keim Hall, Lincoln, NE 68583-0915.

${ }^{2}$ Research Horticulturist. Present address: Shandong Research Institute of Pomology, 64 Longtan Road, Taian, Shandong 271000, P.R. China.

${ }^{3}$ Research Plant Physiologist; to whom reprint requests should be addressed.

${ }^{4}$ Research Plant Pathologist.
We previously showed that PNRSV is consistently transferred across micrografts from infected, decapitated, in-vitro cultured peach shoots to previously noninfected shoot tips of the same cultivar (autografts), and can be detected by RNA hybridization with a nonradioactively labeled cRNA probe (HeussLaRosa et al., 1995) derived from a fragment of PNRSV isolate PE5 RNA 3 (Crosslin et al., 1992). This probe contains portions of the coat protein gene (Hammond and Crosslin, 1995) and is able to detect both mild and severe strains of PNRSV (Crosslin et al., 1992). In subsequent studies, we hope to: 1) have a steady source of virus-infected 'Suncrest' stem bases for in vitro grafting, 2) test tips of peach transformants (with the coat protein gene of PNRSV) grafted onto PNRSV-infected 'Suncrest' bases (heterografts, with base and tip from different cultivars) for response to PNRSV year-round, and 3) detect replicating virus and not the coat protein gene in transgenic plants. In the present study, we investigated whether cultured shoots maintain virus infection under conditions of long-term culture, including extensive periods of storage at $4{ }^{\circ} \mathrm{C}$. We have also tested our micrografting procedure on three peach genotypes, and used a cRNA probe derived from the noncoat protein region of the PNRSV genome to detect virus.
Virus-infected peach shoot cultures were initiated (Hammerschlag, 1982) from shoots collected from a 'Suncrest' tree that had tested positive for PNRSV by enzyme-linked immunosorbent assay (ELISA) (Crosslin et al., 1992). Unless noted otherwise, these shoots were maintained under a regimen consisting of alternating treatments of up to 6 months at $26^{\circ} \mathrm{C}$ (16-h photoperiod, $40 \mu \mathrm{mol} \cdot \mathrm{m}^{-2} \cdot \mathrm{s}^{-1}$ photosynthetically active radiation provided by cool-white fluorescent lamps) with transfers every 2 weeks to fresh elongation medium (Hammerschlag, 1982) and of 6 weeks or more at $4{ }^{\circ} \mathrm{C}$ in the dark on elongation medium (Hammerschlag, 1982) containing 3\% (w/v) sucrose, but without IBA and BA. Noninfected test shoots, used for micrografting, were initiated from shoots collected from 'Suncrest' and 'Springcrest' field-grown trees and from 'Nemaguard' greenhouse-grown trees, and were found to be free of PNRSV and prune dwarf virus by RNA hybridization (data not shown). Immediately before grafting, PNRSVinfected and noninfected shoots were grown for 6 to 9 weeks at $4{ }^{\circ} \mathrm{C}$, followed by 2 to 3 weeks at $26^{\circ} \mathrm{C}$.

To investigate whether cultured shoots maintain virus infection under conditions of long-term culture, two sets of shoots initiated from PNRSV-infected 'Suncrest' trees were chosen to undergo 24 months of in vitro culture terminating with $4{ }^{\circ} \mathrm{C}$ treatments of either 4 or 16 months. Previous to these cold treatments, all shoots were maintained on elongation medium (Hammerschlag, 1982) at $26^{\circ} \mathrm{C}$ with one $4{ }^{\circ} \mathrm{C}$ treatment for 6 weeks, started 3 months after shoot-culture initiation. Leaf samples were taken $14 \mathrm{~d}$ after removal of shoots from the cold, and were processed as described below. This experiment was replicated twice with nine shoots per treatment per replication.

The micrografting of noninfected shoot tips onto infected bases was performed as described previously (Heuss-LaRosa et al., 1995). The micrografts were set up in three blocks, with each block containing a minimum of eight micrografts for each genotype. After placing the micrografts on fresh elongation medium, a sample of two young leaves was collected from the unused portions of the infected and noninfected shoots for the dotblot analyses. Micrografts were transferred to fresh elongation medium every 2 weeks, and samples consisting of the lowest folded leaf plus the leaf immediately below were collected from the grafted tips of four grafts per genotype per block. Samples were taken at each time of shoot transfer, through 6 weeks after grafting.

Nucleic acids were extracted from the tissue samples as described previously (Crosslin et al., 1992; Heuss-LaRosa et al., 1995). For the PNRSV-infected shoots after the 4- and 16 -month cold treatments, $3-\mu \mathrm{L}$ aliquots of a dilution series of sample nucleic acid, corresponding to $1,0.1$, and $0.01 \mu \mathrm{g}$ fresh weight of tissue, were spotted onto positively charged nylon membranes (Boehringer-Mannheim, Indianapolis). For the micrografting experi- 
ment, a 3-fold dilution series of each leaf sample was applied using a Bio-Dot SF apparatus (Bio-Rad, Richmond, Calif.). Each membrane contained the complete set of timecourse samples from two different micrografts. A positive control consisted of pooled samples of leaf extracts from PNRSV-infected cultured 'Suncrest' shoots. Pooled samples of leaf extracts from noninfected shoots served as a negative control.

For detection of PNRSV, the complementary RNA probe used previously (HeussLaRosa et al., 1995) was modified by the following procedure. The pGEM plasmid from which the previous probe was transcribed contains an insert corresponding to a $800 \mathrm{bp}$ portion of PNRSV RNA 3 (Crosslin et al., 1992). This insert spans portions of both open reading frame 1 (ORF 1), encoding the putative movement protein, and ORF 2, which encodes the viral coat protein and contains two HindIII sites, one within the insert, $13 \mathrm{bp} 5^{\prime}$ to the start of ORF 2, and the other originating from the vector insertion site $3^{\prime}$ to the viral sequence (Hammond and Crosslin, 1995). To produce a probe that would not hybridize with the viral coat protein gene, and thus would not detect a viral coat protein transgene, this plasmid was digested with HindIII, and religated with T4 ligase, resulting in an insert corresponding only to ORF 1 of PNRSV RNA 3. This modified probe would be expected to detect only replicating virus. Digoxigeninlabeled RNA was transcribed as described (Heuss-LaRosa et al., 1995), resulting in a 612 bp antisense transcript corresponding to 551 bp of ORF 1 plus $61 \mathrm{bp}$ of the intergenic region. Analysis by hybridization was carried out using the Boehringer-Mannheim antidigoxigenin detection system described previously (Heuss-LaRosa et al., 1995).

After analysis of films by densitometry on an LKB Ultroscan XL (Heuss-LaRosa et al., 1995), the peak areas for different dilutions of graft extracts or for the positive control that fell between 0.01 and 1.0 absorbance units were divided by milligrams of leaf tissue. The mean values for the different dilutions were then calculated for each extract and for the positive control. Relative virus concentration in each tissue sample was calculated by dividing the mean value for each extract by the mean value of the positive control for its blot.

Relative virus concentration values were evaluated for possible differences among the three peach genotypes. The data were analyzed as a mixed covariate repeated measures model using PROC MIXED (SAS Institute, 1992). BLOCK was a random factor, SOURCE was the covariate, and WEEK2, WEEK4, and WEEK6 were the repeated factors. Genotypes were the three cultivars. The virus concentration, CONCENT, was the dependent variable. To correct for variance heterogeneity,

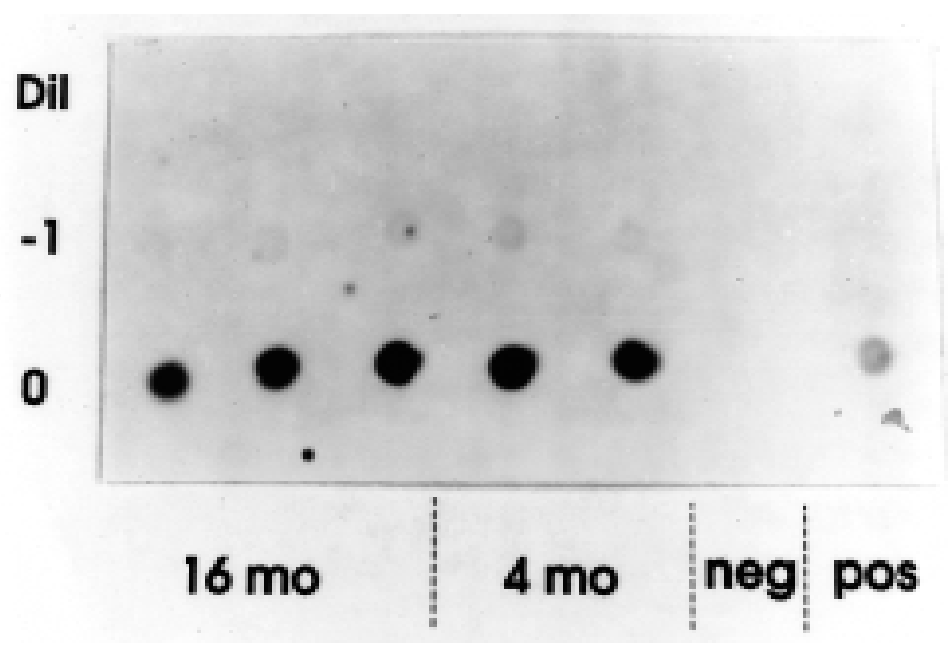

Fig. 1. Dot-blot hybridization on extracts of 'Suncrest' shoots taken from infected field trees, and sampled after either 4 or 16 months of in vitro treatment at $4{ }^{\circ} \mathrm{C}$ in the dark. $0=0.33 \mu \mathrm{g}$ and $-1=0.03 \mu \mathrm{g}$ tissue/ $\mu \mathrm{L}$. The positive control consisted of pooled samples of leaf extracts from cultured 'Suncrest' peach shoots infected with PNRSV. Pooled samples of leaf extracts from noninfected shoots served as the negative control.

CONCENT was $\log _{10}$ transformed, and the transformed variable was used in the analysis.

\section{Results and Discussion}

After cold treatments of either 4 or 16 months, RNA-RNA dot-blot hybridization (Fig. 1) indicated that PNRSV was retained in source shoots even after 2 years in vitro.

Grafts were considered successful if by 2 weeks after grafting, the tips had grown sufficiently to allow sampling. Rates of graft success were $61 \% \pm 6.3 \%$ for grafts of 'Suncrest' tips onto infected 'Suncrest' bases, $84 \% \pm$ $3.0 \%$ and $77 \% \pm 13.1 \%$, respectively, for grafts of 'Springcrest' and 'Nemaguard' tips onto infected 'Suncrest' bases. Leaf samples from all but one of the 'Suncrest' shoots used as bases in successful grafts were shown by RNA hybridization analysis to contain virus (data not shown).

The highest average virus concentration in grafted scions, as calculated from densitometry, occurred in grafted tips 2 weeks after grafting in all three cultivars. Virus concentrations in scions at 2 weeks were three to six times those in graft bases and two to six times those in tips at either 4 or 6 weeks after grafting. There was a statistically significant difference $(P \leq 0.001)$ between the weeks, but no statistical difference between the cultivars or between the source shoots.

The probe used in this study consisted of the sequence complementary to the $5^{\prime}$ open reading frame (ORF 1) of RNA 3. This probe detected virus infection equally as well as the probe used previously (Heuss-LaRosa et al., 1995), which spanned a portion of the coat protein gene (ORF 2), as well as the $5^{\prime}$ open reading frame (ORF 1) of RNA 3 (Hammond and Crosslin, 1995)

In conclusion, we found that 'Suncrest' stem bases were useful for testing the response of transgenic peach tips to PNRSV because of their ability to retain virus even after longterm culture and because of the high rate of success for heterografts. In addition, the present probe should be useful in subsequent studies with transformants containing the introduced PNRSV coat protein gene, since this probe should detect only virus and not endogenous expression of coat protein RNA in transgenic peach.

\section{Literature Cited}

Crosslin, J.M., R.W. Hammond, and F.A. Hammerschlag. 1992. Detection of Prunus necrotic ringspot virus serotypes in herbaceous and Prunus hosts with a complementary RNA probe. Plant Dis. 76:1132-1136.

Hammerschlag, F.A. 1982. Factors affecting establishment and growth of peach shoots in vitro. HortScience 17:85-86.

Hammond, R.W. and J.M. Crosslin. 1995. The complete nucleotide sequence of RNA 3 of a peach isolate of Prunus necrotic ringspot virus. Virology 208:349-353.

Heuss-LaRosa, K., R. Hammond, J.M. Crosslin, C. Hazel, and F.A. Hammerschlag. 1995. Monitoring Prunus necrotic ringspot virus infection by hybridization with a cRNA probe following in vitro micrografting. J. Amer. Soc. Hort. Sci. 120:928-931.

Hull, R. and J.W. Davies. 1992. Approaches to nonconventional control of plant virus diseases. Crit. Rev. Plant Sci. 11:17-33.

SAS Institute. 1992. SAS technical report P-229, SAS/STAT software: Changes and enhancements, release 6.07. SAS Inst., Cary, N.C. 